\title{
ZASTOSOWANIE NARZĘDZI ICT W TERENOWYCH STRUKTURACH ORGANIZACJI X
}

\author{
Aida Stępniak ${ }^{1}$ \\ Politechnika Częstochowska \\ Wydział Zarządzania
}

\begin{abstract}
Streszczenie: Technologia informacyjna i szeroko rozumiane narzędzia ICT stają się nieodłącznym elementem coraz większej liczby dziedzin życia i działalności publicznej. Celem niniejszej publikacji jest identyfikacja potrzeb w zakresie zastosowania narzędzi ICT w zarządzaniu terenowymi strukturami organizacji X. Dla realizacji celu artykułu przeprowadzono studium przypadku poprzez wywiady konceptualne z kierownikiem terenowego oddziału organizacji X. Zebrane dane przeanalizowano, a następnie omówiono najważniejsze powody zastosowania wybranych narzędzi mających wpływ na zarządzanie w opisywanej organizacji oraz potencjalne kierunki rozwoju tematyki.
\end{abstract}

Słowa kluczowe: gospodarka elektroniczna, narzędzia ICT, organizacje rozproszone, społeczeństwo informacyjne, struktury terenowe, technologia informacyjna

DOI: 10.17512 /znpcz.2020.3.06

\section{Wprowadzenie}

Technologia informacyjna staje się coraz bardziej powszechnym elementem niemal wszystkich dziedzin życia (Chomiak-Orsa 2016, s. 40) i zmienia standardy przekazywania wiedzy i informacji (Kisielnicki 2015, s. 18). Na coraz szerszą skalę jest wykorzystywana nie tylko przez osoby prywatne, ale także różnego typu organizacje. Jak zauważa D. Jelonek (Jelonek 2018, s. 48), przedsiębiorstwa nie mogą pozostawać zamknięte na trendy, które mogą okazać się istotne dla branż, w których działają, albo dla ich klientów, co może zaowocować zmianą profilu ich potrzeb. Trend ten nie omija również podmiotów powołanych do prowadzenia działalności społecznej i angażujących się w życie publiczne $\mathrm{w}$ różnej formie, takich jak fundacje, stowarzyszenia i inne. Tego typu podmioty są organizacjami (por.: Adamik, Matejun 2012, s. 41-59; Wierzbica 2017, s. 124-134), a zatem - jak każda organizacja - by realizować swoje cele, wymagają sprawnego zarządzania. Zarządzanie odnosi się do organizacji jako całości, jak i do jej struktur terenowych, szczególnie w przypadku organizacji rozproszonych (por.: Pawełoszek 2012, s. 327-328; Woźniak, Zaskórski 2013, s. 413). Organizacje realizujące cele społeczne i własne programy mające na celu zmiany w życiu publicznym czerpią $\mathrm{z}$ dorobku nauk o zarządzaniu w różnorodnych kwestiach, zarówno w obszarze organizacyjnym, tworzenia strategii, marketingu, jak i menedżerskiego wykorzystania technologii informacyjnej w różnorodnych formach. Struktury terenowe są potrzebne do osiągnięcia sukcesu i realizacji celów przez organizacje uczestniczące w życiu publicznym na dużą skalę. Z tego

\footnotetext{
${ }^{1}$ Aida Stępniak, mgr, ainethegenie@op.pl, ORCID: 0000-0002-7731-4046
} 
względu dla sprawnego funkcjonowania organizacji o rozproszonym charakterze ważną rolę pełni komunikacja i wymiana zasobów informacyjnych.

W literaturze spotkać można różnorodne definicje terminu „ICT”. Kładzie się w nich nacisk m.in. na takie kwestie jak dostęp do informacji poprzez telekomunikację, technologie głosowe i sieciowe, przetwarzanie informacji czy cele komunikacyjne (por.: Zuppo 2012, s. 16). Polski Główny Urząd Statystyczny pojęcie „technologie informacyjno-komunikacyjne” definiuje w następujący sposób: „Rodzina technologii przetwarzających, gromadzących i przesyłających informacje w formie elektronicznej” (https://stat. gov.pl/...). Jako synonimy uznawane są określenia: „technologie teleinformacyjne” oraz „ICT” (ang. Information and Communication Techologies) (https://stat.gov.pl/...).

Termin został wprowadzony do dyskursu w ostatniej dekadzie XX wieku, a do opisywanych technologii zalicza się różnorodne media komunikacyjne, media, dzięki którym możliwe jest zapisywanie informacji, złożone systemy, informatyczne aplikacje oraz umożliwiający przetwarzanie informacji sprzęt (Leoński 2014, s. 182-183). Ten szeroki zakres technologiczny przyczynia się do rozwoju społeczeństwa opartego na wiedzy (Warzecha 2018, s. 116), społeczeństwa informacyjnego (Jelonek 2011, s. 46; por.: Martin 2017, s. 1-14; Kiercz 2013, s. 44; Goliński 2011, s. 23-32; Kłak 2010, s. 113-120) i gospodarki elektronicznej. Jest to swoiste sprzężenie zwrotne, albowiem i same technologie informacyjno-komunikacyjne mają wpływ na zmiany społeczno-gospodarczo-kulturowe (Kobyliński 2011, s. 283). Zauważa się wpływ technologii ICT na różne sektory gospodarki, także na sektor usług pozarynkowych (Kos-Łabędowicz 2016, s. 160), a także możliwość wspomagania osiągania przewagi konkurencyjnej, wsparcie procesów decyzyjnych, poprawy efektywności organizacyjnej czy twórcze rozwiązywanie problemów (Olszak 2016, s. 81-82).

Różnorodność narzędzi ICT (por.: Sołtysik-Piorunkiewicz, Furmankiewicz, Ziuziański 2016, s. 88) sprawia, że ich wykorzystanie jest nie tylko możliwe, ale i atrakcyjne dla różnorodnych organizacji, również nienastawionych na zysk w kategoriach finansowych. Wśród nich znajdują się także organizacje stworzone dla angażowania się w życie publiczne. Może to wspomagać realizację ich statutowych i merytorycznych celów. Za cel artykułu obrano identyfikację potrzeb w zakresie zastosowania narzędzi ICT w zarządzaniu terenowymi strukturami organizacji X, która powołana została, by angażować się w życie publiczne.

\section{Cel i metodologia badawcza}

Celem badań jest identyfikacja współcześnie występujących narzędzi ICT, które znajdują zastosowanie w organizacjach powołanych nie dla zysku, lecz dla promowania postaw, wartości oraz angażowania się w życie publiczne. Postawione zostały trzy hipotezy badawcze:

H1: Narzędzia ICT są wykorzystywane w strukturach terenowych organizacji powołanych do angażowania się w życie publiczne.

H2: Narzędzia ICT usprawniają procesy zarządzania i osiąganie celów przez struktury terenowe organizacji powołanych do angażowania się w życie publiczne.

H3: Członkowie struktur terenowych organizacji powołanych do angażowania się w życie publiczne dostrzegają potencjał zastosowania nowych narzędzi ICT i technologii. 
Dla weryfikacji hipotez i osiągnięcia założonego celu badawczego przeprowadzono studium przypadku (por.: Tomski 2017, s. 189). Obiektem case study są okręgowe struktury terenowe jednej z polskich organizacji zaangażowanych w życie publiczne.

Badania były prowadzone poprzez wywiady konceptualne z prezesem opisywanej jednostki (jako głównym odpowiedzialnym za działalność jednostki terenowej). Odpowiedzi bazowały także na informacjach otrzymanych od innych działaczy okręgowych. Wywiady prowadzone były osobiście w II kwartale 2020 roku. Na początku prezes wskazał statut organizacji jako źródło obowiązków nakładanych na struktury terenowe oraz podstawowych zasad zarządzania podmiotem. Po uzyskaniu tej informacji przeprowadzono analizę dokumentacji i wyodrębniono, a dalej opisano cele i obowiązki działania badanej jednostki organizacyjnej. Następnie przygotowano scenariusz wywiadu kwestionariuszowego, na podstawie którego wyodrębniono również inne, niewynikające ze statutu organizacji obowiązki nakładane na struktury terenowe, po czym przyporządkowano podejmowane przez działaczy działania do celów, których realizacji mają one służyć. W dalszej kolejności wymieniono stosowane przy poszczególnych działaniach narzędzia ICT wspomagające ich realizację, a następnie stworzono również listę rozwiązań technologicznych, które działacze uznają za potencjalnie przydatne w prowadzeniu konkretnych typów działalności. Po uzyskaniu opisanych danych uporządkowano je w formie tabelarycznej, poddano analizie, przyporządkowano cele do jednego $\mathrm{z}$ trzech wyodrębnionych obszarów, a następnie przedstawiono wnioski. Prezes opisywanej jednostki terenowej nie wyraził zgody na podanie w artykule nazwy organizacji oraz szczegółów umożliwiających jej identyfikację. $Z$ tego względu nie jest możliwe przytoczenie konkretnych przykładów działań czy wydarzeń prowadzonych przez badaną jednostkę.

\section{Statutowe cele struktur terenowych opisywanej organizacji}

Polskie prawodawstwo szczegółowo reguluje oraz definiuje rodzaj działalności prowadzonej przez opisywaną organizację (Ustawa z dnia 27 czerwca 1997 r. o partiach politycznych). Między innymi określa, że tego typu podmioty bazują na społecznej pracy członków, dopuszcza się jednak również zatrudnianie pracowników.

Statut opisywanej organizacji precyzuje strukturę organizacyjną podmiotu oraz sposób jego działania. Rozstrzygnięcia organów kolegialnych podejmowane są w formie uchwał zwykłą większością głosów, do czego niezbędna jest obecność minimum połowy posiadających prawo głosowania, zaś władze jednoosobowe swoje rozstrzygnięcia podejmują w postaci zarządzeń (statut opisywanej organizacji). Statut dopuszcza zwoływanie posiedzeń organów kolegialnych drogą elektroniczną pod warunkiem zachowania formy pisemnej. Również prowadzenie obrad i podejmowanie uchwał może odbywać się przy pomocy środków komunikowania się na odległość poprzez wideokonferencje, z użyciem telefonu lub komunikacji internetowej, a rozstrzygnięcia organów organizacji mogą być doręczane drogą elektroniczną. Wyjątek stanowią sytuacje podlegające innym przepisom szczególnym i określonym osobną uchwałą jednego $\mathrm{z}$ organów organizacji (statut opisywanej organizacji). 
Również wystąpienie z organizacji może dokonać się na podstawie oświadczenia woli złożonego drogą elektroniczną (statut opisywanej organizacji).

Statut reguluje kwestie podstawowych jednostek organizacyjnych oraz ewentualnej możliwości tworzenia podjednostek. Określa też skład i zadania organów jednostek terenowych. Do kompetencji organów struktur terenowych należy formułowanie opinii dotyczącej aktywności publicznej organizacji na terenie, na którym operuje, oraz przygotowanie lokalnego programu działalności w porozumieniu z organami centralnymi, formułowanie stanowisk dotyczących bieżącej działalności publicznej, jak również wysuwanie propozycji działań na obszarze funkcjonowania. Zadania te mają być realizowane zgodnie ze statutem, uchwałami organów krajowych i programem organizacji (statut opisywanej organizacji).

Prezes zobowiązany jest do zwoływania i kierowania pracami organów jednostki terenowej oraz zewnętrznego reprezentowania organizacji. W szczególnych przypadkach może go zastąpić jeden $\mathrm{z}$ wiceprezesów, których obowiązkiem jest wspieranie prezesa w wykonywaniu obowiązków płynących z uchwał i statutu. Do obowiązków sekretarza należy protokołowanie posiedzeń organów jednostki, archiwizacja dokumentów i kopii deklaracji członkowskich, przygotowywanie projektów uchwał organów oraz współpraca $\mathrm{z}$ władzami centralnymi, w tym przekazywanie odpisów uchwał organów jednostki terenowej. Z kolei skarbnik ma za zadanie sprawować pieczę nad terminowością wpłaty składek członkowskich, prowadzić dokładną ewidencję okręgowych wpływów i wydatków, minimum dwukrotnie w ciągu roku przedstawić sprawozdanie $\mathrm{z}$ działalności finansowej organom struktur terenowych oraz $\mathrm{w}$ określonych terminach składać sprawozdanie $z$ działalności finansowej na ręce skarbnika krajowego.

Oprócz zadań statutowych władze centralne zlecają strukturom okręgowym realizację różnorodnych zadań. Należą do nich np. akcje ogólnopolskie polegające na organizacji podobnego typu wydarzeń, konferencji prasowych czy performance'ów w całym kraju, szeroko rozumiane czynności związane z cyklicznymi lokalnymi działaniami angażującymi w życie publiczne (np. spełnianie wymagań formalnych określonych w odrębnych przepisach, rekrutacja do organów nadzoru obywatelskiego, kolportaż materiałów przygotowanych przez organizację, organizowanie spotkań na terenie działalności jednostki terenowej) komunikacja z lokalnymi mediami, budowanie marki podmiotu oraz współpraca z miejscowymi organizacjami. Same władze lokalnych struktur organizacji mają również możliwość tworzenia własnych inicjatyw, do których mogą wykorzystywać dowolne narzędzia z zachowaniem odpowiednich przepisów wewnętrznych oraz prawa powszechnego.

\section{Powiązanie celów i działań analizowanych struktur terenowych organizacji X z wykorzystaniem narzędzi ICT}

Na podstawie analizy dokumentacji wskazanej przez prezesa lokalnych struktur wyodrębniono cele stawiane przed tą jednostką organizacyjną. Następnie na drodze wywiadu konceptualnego celom przyporządkowano służące do ich realizacji działania oraz wykorzystywane do tego narzędzia ICT. Ostatnim krokiem było zidentyfikowanie innych narzędzi ICT, niewykorzystywanych dotychczas, lecz potencjalnie 
przydatnych do osiągania zidentyfikowanych celów. Wyniki przeprowadzonych wywiadów zostały zaprezentowane w Tabeli 1, Tabeli 2 i Tabeli 3.

W Tabeli 1 przedstawiono cele, odpowiadające im działania oraz wykorzystywane i możliwe do zastosowania technologie ICT w obszarze zarządzania jednostką $\mathrm{w}$ analizowanej strukturze terenowej organizacji X. Obszar ten obejmuje zagadnienia związane z planowaniem, organizowaniem, motywowaniem i kontrolą oraz szeroko rozumianym marketingiem podmiotu.

Tabela 1. Cele, odpowiadające im działania oraz wykorzystywane i możliwe do wykorzystania narzędzia ICT $w$ analizowanych strukturach terenowych organizacji X w obszarze zarządzania jednostką

\begin{tabular}{|c|c|c|c|}
\hline Cele & Działania & $\begin{array}{l}\text { Wykorzystywane } \\
\text { narzędzia ICT }\end{array}$ & $\begin{array}{c}\text { Możliwe do } \\
\text { wykorzystania } \\
\text { narzędzia ICT } \\
\end{array}$ \\
\hline $\begin{array}{l}\text { Proponowanie } \\
\text { działań } \\
\text { publicznych }\end{array}$ & $\begin{array}{c}\text { Koncepcyjne } \\
\text { opracowywanie lokalnych } \\
\text { i ogólnopolskich akcji } \\
\text { publicznych }\end{array}$ & \begin{tabular}{|c|} 
Poczta \\
elektroniczna, \\
komunikatory \\
internetowe, media \\
społecznościowe, \\
telekonferencje na \\
ogólnodostępnych \\
platformach, \\
telefonia
\end{tabular} & $\begin{array}{l}\text { Aplikacje } \\
\text { wspomagające } \\
\text { kreatywne } \\
\text { myślenie, } \\
\text { oprogramowanie } \\
\text { do zarządzania } \\
\text { projektami, } \\
\text { analiza } \\
\text { sentymentu }\end{array}$ \\
\hline $\begin{array}{l}\text { Przygotowywanie } \\
\text { projektów uchwał }\end{array}$ & $\begin{array}{c}\text { Identyfikacja kwestii } \\
\text { niezbędnych do } \\
\text { uregulowania } \\
\text { legislacyjnego } \\
\text { Merytoryczne i edycyjne } \\
\text { przygotowanie projektu } \\
\text { uchwały }\end{array}$ & \begin{tabular}{|} 
Programy \\
edytorskie, poczta \\
elektroniczna, \\
komunikatory \\
internetowe, media \\
społecznościowe
\end{tabular} & $\begin{array}{c}\text { Podpis } \\
\text { elektroniczny, } \\
\text { baza wzorów } \\
\text { dokumentów, } \\
\text { kreator } \\
\text { dokumentów }\end{array}$ \\
\hline $\begin{array}{l}\text { Kontrola } \\
\text { działalności } \\
\text { finansowej }\end{array}$ & $\begin{array}{l}\text { Bieżące prowadzenie spraw } \\
\text { finansowych } \\
\text { Kontrola prawidłowości } \\
\text { wydatkowania funduszy }\end{array}$ & $\begin{array}{c}\text { Bankowość } \\
\text { elektroniczna, } \\
\text { poczta elektroniczna }\end{array}$ & $\begin{array}{c}\text { Kastomizowany } \\
\text { program } \\
\text { księgowy }\end{array}$ \\
\hline $\begin{array}{l}\text { Organizowanie } \\
\text { lokalnych działań } \\
\text { angażujących } \\
\text { w życie publiczne }\end{array}$ & $\begin{array}{c}\text { Spełnianie wymagań } \\
\text { formalnych } \\
\text { Rekrutacja do organów } \\
\text { obywatelskich } \\
\text { Kolportaż materiałów } \\
\text { przygotowanych przez } \\
\text { organizację } \\
\text { Promocja organizacji } \\
\text { i związanych z nią osób oraz } \\
\text { podmiotów }\end{array}$ & \begin{tabular}{|c|} 
Poczta \\
elektroniczna, \\
komunikatory \\
internetowe, media \\
społecznościowe, \\
dyski w chmurze, \\
telekonferencje na \\
ogólnodostępnych \\
platformach, fora \\
dyskusyjne, portale \\
ogłoszeniowe, wła- \\
sne witryny interne- \\
towe, telefonia
\end{tabular} & $\begin{array}{l}\text { Oprogramowanie } \\
\text { do tworzenia } \\
\text { newsletterów, } \\
\text { system rekrutacji } \\
\text { do obwodowych } \\
\text { komisji wybor- } \\
\text { czych, kwalifiko- } \\
\text { wany ogólnopol- } \\
\text { ski podpis } \\
\text { elektroniczny, } \\
\text { partyjna aplikacja } \\
\text { mobilna }\end{array}$ \\
\hline
\end{tabular}




\begin{tabular}{|c|c|c|c|}
\hline & Tworzenie i kolportaż & Poczta & \\
& gadżetów z logo organizacji & elektroniczna, & \\
& Udział w lokalnych & komunikatory & Oprogramowanie \\
Budowanie & uroczystościach i obchodach & internetowe, media & do tworzenia \\
Różne formy współpracy & społecznościowe, & newsletterów, \\
programy \\
i promocja marki & z innymi organizacjami & dyski w chmurze, & graficzne \\
oraz współpraca & Organizacja spotkań & telekonferencje na & grafick \\
z lokalnymi & rekrutacyjnych & ogólnodostępnych & i statystyczne, \\
organizacjami & Organizacja wykładów & platformach, fora & analiza \\
& otwartych & dyskusyjne, własne & sentymentu, \\
& Konferencje & witryny & vlogi \\
& prasowe i happeningi & internetowe, blogi, & \\
& telefonia & \\
\hline
\end{tabular}

Źródło: Opracowanie własne

W Tabeli 2 przedstawiono cele, odpowiadające im działania oraz wykorzystywane i możliwe do zastosowania technologie ICT w obszarze komunikacji z centralą organizacji w analizowanej strukturze terenowej organizacji X. Obszar ten dotyczy kwestii, w których wymagane jest zaangażowanie, współdziałanie lub sprawozdawczość dla organów krajowych opisywanej organizacji.

Tabela 2. Cele, odpowiadające im działania oraz wykorzystywane i możliwe do wykorzystania narzędzia ICT $\mathrm{w}$ analizowanych strukturach terenowych organizacji $X$ w komunikacji $z$ centralą organizacji

\begin{tabular}{|c|c|c|c|}
\hline Cele & Działania & $\begin{array}{l}\text { Wykorzystywane } \\
\text { narzędzia ICT }\end{array}$ & $\begin{array}{c}\text { Możliwe do wykorzystania } \\
\text { narzędzia ICT }\end{array}$ \\
\hline $\begin{array}{c}\text { Protokołowanie } \\
\text { i archiwizacja } \\
\text { dokumentów }\end{array}$ & $\begin{array}{c}\text { Tworzenie protokołów } \\
\text { ze spotkań } \\
\text { Archiwizowanie } \\
\text { dokumentów }\end{array}$ & $\begin{array}{c}\text { Programy edytor- } \\
\text { skie, poczta elektro- } \\
\text { niczna }\end{array}$ & $\begin{array}{c}\text { Programy do zamiany mowy } \\
\text { na tekst, system archiwizacji } \\
\text { dokumentów, podpis } \\
\text { elektroniczny }\end{array}$ \\
\hline $\begin{array}{l}\text { Współpraca } \\
\text { z władzami } \\
\text { centralnymi }\end{array}$ & $\begin{array}{l}\text { Uczestnictwo } \\
\text { w spotkaniach } \\
\text { organów centralnych } \\
\text { Organizacja akcji } \\
\text { ogólnopolskich } \\
\text { Współpraca przy } \\
\text { ogólnokrajowych } \\
\text { działaniach } \\
\text { angażujących w życie } \\
\text { publiczne } \\
\text { Wysuwanie } \\
\text { propozycji aktywności } \\
\text { publicznych }\end{array}$ & $\begin{array}{c}\text { Poczta elektro- } \\
\text { niczna, komunika- } \\
\text { tory internetowe, } \\
\text { media społeczno- } \\
\text { ściowe, programy } \\
\text { edytorskie, dyski } \\
\text { w chmurze, telekon- } \\
\text { ferencje na ogólno- } \\
\text { dostępnych platfor- } \\
\text { mach, telefonia }\end{array}$ & $\begin{array}{l}\text { Oprogramowanie do zarzą- } \\
\text { dzania projektami, system au- } \\
\text { tomatyzacji przekazywania } \\
\text { dokumentów, aplikacje do } \\
\text { szyfrowanych telekonferen- } \\
\text { cji, szyfrowane komunikatory } \\
\text { internetowe, powszechne } \\
\text { partyjne skrzynki mailowe, } \\
\text { organizacyjny Intranet, } \\
\text { organizacyjna aplikacja } \\
\text { mobilna, elektroniczny planer } \\
\text { wydarzeń }\end{array}$ \\
\hline $\begin{array}{l}\text { Sprawozdaw- } \\
\text { czość finansowa } \\
\text { dla organów } \\
\text { centralnych }\end{array}$ & $\begin{array}{c}\text { Tworzenie } \\
\text { i raportowanie } \\
\text { rocznych sprawozdan } \\
\text { finansowych }\end{array}$ & $\begin{array}{c}\text { Bankowość } \\
\text { elektroniczna, } \\
\text { poczta elektroniczna }\end{array}$ & $\begin{array}{c}\text { System automatyzacji } \\
\text { przekazywania dokumentów, } \\
\text { kastomizowany program } \\
\text { księgowy }\end{array}$ \\
\hline
\end{tabular}

Źródło: Opracowanie własne 
W Tabeli 3 przedstawiono cele, odpowiadające im działania oraz wykorzystywane i możliwe do zastosowania technologie ICT w obszarze bieżącej działalności $\mathrm{w}$ analizowanej strukturze terenowej organizacji X. Ten obszar obejmuje wszelkie działania cykliczne odbywające się według ustalonych procedur i nie wymaga każdorazowego podejmowania decyzji menedżerskich.

Tabela 3. Cele, odpowiadające im dzialania oraz wykorzystywane i możliwe do wykorzystania narzędzia ICT $w$ analizowanych strukturach terenowych organizacji $\mathrm{X}$ w obszarze bieżącej działalności organizacji

\begin{tabular}{|c|c|c|c|}
\hline Cele & Działania & $\begin{array}{l}\text { Wykorzystywane } \\
\text { narzędzia ICT }\end{array}$ & $\begin{array}{c}\text { Możliwe } \\
\text { do wykorzystania } \\
\text { narzędzia ICT }\end{array}$ \\
\hline $\begin{array}{l}\text { Formułowanie } \\
\text { opinii } \\
\text { i przygotowanie } \\
\text { programu }\end{array}$ & $\begin{array}{c}\text { Formułowanie } \\
\text { stanowisk } \\
\text { w sprawach wydarzeń } \\
\text { bieżących } \\
\text { Opracowywanie } \\
\text { lokalnych programów } \\
\text { działalności } \\
\text { Przygotowywanie } \\
\text { ogólnokrajowych } \\
\text { propozycji }\end{array}$ & $\begin{array}{c}\text { Komunikatory } \\
\text { internetowe, } \\
\text { programy edytorskie, } \\
\text { media społeczno- } \\
\text { ściowe, dyski } \\
\text { w chmurze, telekon- } \\
\text { ferencje na ogólnodo- } \\
\text { stępnych platfor- } \\
\text { mach, telefonia }\end{array}$ & $\begin{array}{l}\text { Programy graficzne } \\
\text { i statystyczne, } \\
\text { szyfrowane } \\
\text { platformy do prowa- } \\
\text { dzenia telekonferen- } \\
\text { cji, szyfrowane } \\
\text { komunikatory } \\
\text { internetowe, opro- } \\
\text { gramowanie do za- } \\
\text { rządzania projektami }\end{array}$ \\
\hline $\begin{array}{c}\text { Zwoływanie } \\
\text { i prowadzenie } \\
\text { zebrań organów } \\
\text { jednostki terenowej } \\
\text { organizacji }\end{array}$ & $\begin{array}{c}\text { Powiadamianie } \\
\text { o zebraniach organów } \\
\text { Prowadzenie zebrań } \\
\text { organów } \\
\text { Raportowanie } \\
\text { postanowień organów }\end{array}$ & $\begin{array}{c}\text { Poczta elektroniczna, } \\
\text { komunikatory } \\
\text { internetowe, media } \\
\text { społecznościowe, } \\
\text { telekonferencje na } \\
\text { ogólnodostępnych } \\
\text { platformach, } \\
\text { programy edytorskie }\end{array}$ & $\begin{array}{c}\text { Powszechne partyjne } \\
\text { skrzynki mailowe, } \\
\text { partyjna aplikacja } \\
\text { mobilna, } \\
\text { elektroniczny planer } \\
\text { wydarzeń, aplikacje } \\
\text { do szyfrowanych } \\
\text { telekonferencji, } \\
\text { szyfrowane komuni- } \\
\text { katory internetowe }\end{array}$ \\
\hline $\begin{array}{c}\text { Reprezentowanie } \\
\text { jednostki terenowej } \\
\text { organizacji }\end{array}$ & $\begin{array}{l}\text { Udział w spotkaniach } \\
\text { organów centralnych } \\
\text { Udzielanie wywiadów } \\
\text { i wypowiedzi medial- } \\
\text { nych } \\
\text { Udział w lokalnych } \\
\text { uroczystościach }\end{array}$ & $\begin{array}{c}\text { Poczta elektroniczna, } \\
\text { komunikatory } \\
\text { internetowe, media } \\
\text { społecznościowe, } \\
\text { telekonferencje na } \\
\text { ogólnodostępnych } \\
\text { platformach, } \\
\text { telefonia }\end{array}$ & $\begin{array}{l}\text { Powszechne partyjne } \\
\text { skrzynki mailowe, } \\
\text { partyjny intranet, } \\
\text { aplikacje do szyfro- } \\
\text { wanych telekonferen- } \\
\text { cji, szyfrowane } \\
\text { komunikatory } \\
\text { internetowe }\end{array}$ \\
\hline $\begin{array}{l}\text { Komunikacja } \\
\text { z lokalnymi } \\
\text { mediami }\end{array}$ & $\begin{array}{c}\text { Przekazywanie } \\
\text { informacji prasowych } \\
\text { Organizacja } \\
\text { konferencji } \\
\text { prasowych } \\
\text { Udzielanie wywiadów } \\
\text { i udział w programach } \\
\text { publicystycznych }\end{array}$ & $\begin{array}{l}\text { Poczta elektroniczna, } \\
\text { komunikatory } \\
\text { internetowe, media } \\
\text { społecznościowe, } \\
\text { własne witryny } \\
\text { internetowe, telefonia }\end{array}$ & $\begin{array}{l}\text { Oprogramowanie do } \\
\text { tworzenia } \\
\text { newsletterów, analiza } \\
\text { sentymentu, } \\
\text { programy graficzne } \\
\text { i statystyczne }\end{array}$ \\
\hline
\end{tabular}

Źródło: Opracowanie własne 
Najczęściej stosowanymi w analizowanej organizacji narzędziami elektronicznymi są media społecznościowe (por.: Tomczyk, Pawełoszek-Korek 2019, s. 305-306; Jaska 2018, s. 80-84; Czarnota 2017, s. 130-131), komunikatory internetowe, poczta elektroniczna, programy edytorskie oraz telekonferencje na ogólnodostępnych platformach. W części przypadków wykorzystywane są rozwiązania pozwalające na zapisywanie i udostępnianie plików w chmurze. Podczas wywiadu badawczego wspominane były również rozwiązania umożliwiające sieciowe przesyłanie dużych plików (np. filmów w rozdzielczości HD lub wyższej). Wykorzystanie tych narzędzi ułatwia planowanie, organizowanie, motywowanie i kontrolę w ramach działania organizacji, głównie poprzez usprawnienie komunikacji i zwiększenie tempa przepływu informacji, a także docierania do konkretnych grup interesariuszy. Do specyficznych celów, takich jak kontrola działalności finansowej, używane są kastomizowane narzędzia, jak bankowość elektroniczna. Do przekazywania informacji i budowania wizerunku wśród osób, które nie są członkami organizacji, wykorzystywane są własne witryny internetowe oraz blogi. W przypadku spraw, w których pożądana jest bezpośrednia i szybka interakcja między dwoma osobami, wykorzystuje się także telefonię, w przeważającej mierze komórkową (w tym połączenia głosowe i wiadomości SMS - te drugie rozsyłane także w formie zautomatyzowanych „newsletterów”). Przesyłanie plików odbywa się głównie poprzez komunikację elektroniczną, bez używania nośników zewnętrznych typu płyta czy dysk zewnętrzny (wykorzystanie takich metod przenoszenia informacji mogłoby stworzyć zagrożenie dla zachowania poufności danych).

Organizacja posiada własny system informatyczny, który jest wykorzystywany do niektórych celów zarządczych (takich jak na przykład organizowanie i motywowanie, dzięki ułatwianiu komunikacji z działaczami, a także kontroli zasobów ludzkich i finansowych organizacji), oraz służbowe skrzynki e-mail, które zakładane są osobom pełniącym określone funkcje $\mathrm{w}$ organizacji. Jest podstawowym repozytorium wiedzy organizacyjnej (por.: Zamanani, Izhar 2018, s. 915; Naushad, Jafar 2015, s. 18; Kordel 2010, s. 34; Karwasińska, Rychlik 2008, s. 10) i głównym narzędziem zarządzania wiedzą (por.: Dhakad, Hebalkar 2018, s. 105; Skrzypek 2015, s. 154-158; Klimczok, Tomczyk 2012, s. 167-168; Sharma, Bock 2005, s. 3) w organizacji. System ma jednak ograniczenia, a zauważane braki skłaniają działaczy do poszukiwania bardziej wydajnych i funkcjonalnych rozwiązań, szczególnie gdy są one dostępne za darmo lub wiążą się ze stosunkowo niewielkimi opłatami. Aplikowanie pewnych rozwiązań technologicznych często wynika z pozytywnych doświadczeń działaczy na polu zawodowym lub prywatnym, np. polecają oprogramowanie, z którego sami korzystają oraz służą innym pomocą w nauce jego obsługi i rozwiązują problemy techniczne. $Z$ tego względu w stosunku do centrali organizacji zgłaszane są potencjalne rozwiązania, które mogą zwiększyć efektywność menedżerską w jednostkach terenowych.

Wśród rozwiązań ICT niestosowanych w terenowej działalności organizacji, ale w których działacze widzą potencjał do ułatwienia swojej aktywności, pojawiają się w przeważającej mierze rozwiązania specjalistyczne, wymagające większych nakładów finansowych lub/oraz kompetencji w zakresie ich tworzenia i obsługi. W zakre- 
sie menedżerskim ich największe zastosowanie jest zauważane w obszarach planowania i organizowania działalności. Część z nich - jak tworzone na zamówienie systemy automatyzacji przekazywania i archiwizacji dokumentów, rekrutacji do organów obywatelskich, księgowe, powszechne partyjne skrzynki mailowe czy organizacyjna aplikacja mobilna - najprawdopodobniej wymagałaby wprowadzenia centralnie. Dotyczą one bowiem aspektów, które dotykają w większym lub mniejszym stopniu działaczy z całego kraju lub są związane stricte z komunikacją z centralą organizacji. Najprostszą drogą do wprowadzenia tego typu rozwiązań byłoby stworzenie jednolitego, zintegrowanego i ogólnopolskiego systemu informacyjnego, w pełni dopasowanego do potrzeb organizacji. Wymagałoby to jednak szczegółowego określenia obecnych, jak i potencjalnych przyszłych potrzeb informacyjnych oraz znacznych nakładów finansowych. Podobnie wygląda kwestia narzędzi typowo specjalistycznych, takich jak aplikacje służące do analizy sentymentu (por.: Ziora 2016, s. 234-241; Cambria 2016, s. 102-107). Z kolei programy graficzne czy statystyczne, które nie wymagają aż tak dużych inwestycji pieniężnych, nie będą użyteczne bez odpowiednio przeszkolonych osób, mogących poświęcić czas na wykonywanie zleconych zadań, a takie osoby nie zawsze znajdują się w szeregach danych struktur terenowych. Tacy członkowie musieliby również odbyć przeszkolenie w zakresie centralnie określonej identyfikacji wizualnej organizacji lub statystycznej metodologii badawczej. W opisywanych powyżej kwestiach decyzje menedżerskie i organizacyjne leżą jednak po stronie centrali organizacji.

Innym typem rozwiązań, co do których działacze widzą szersze zastosowanie w terenowej działalności organizacyjnej, są różnego typu aplikacje zwiększające prywatność, poufność i bezpieczeństwo komunikacji oraz przesyłania danych. Przykład tego typu technologii stanowią narzędzia do szyfrowanych telekonferencji i szyfrowane komunikatory. Ich zasadność to konieczność zachowania tajemnicy organizacyjnej, omawiania informacji niejawnych i nieoficjalnych czy prowadzenie negocjacji, które muszą pozostać nieznane szerszemu gronu odbiorców, a także minimalizacji zagrożenia cyberprzestępczością (por.: Oleksiewicz 2019, s. 145) nakierowaną na kradzież własności intelektualnej i informacji poufnych. Jak do tej pory kierownictwo organizacji nie widzi potrzeby aplikowania żadnej formy systemu zarządzania ryzykiem.

Analizowane studium przypadku dowodzi, że technologia informacyjno-komunikacyjna może być przydatnym narzędziem wspomagającym realizację zadań i działania organizacji stworzonych w celu angażowania się w życie publiczne, w tym również ich terenowych struktur. Nawet w przypadku posiadania przez organizację własnego systemu informatycznego lokalne oddziały mogą z powodzeniem wykorzystywać inne rozwiązania ICT, dające dodatkowe możliwości. Te rozwiązania mogą być stosowane jednorazowo lub wejść do kanonu narzędzi, do używania których będzie się zachęcać nowych członków organizacji oraz udzielać im ewentualnej pomocy w przeszkoleniu do ich używania. Przy odpowiednim i powszechnym stosowaniu mogą one znacząco ułatwiać działania i wypełnianie statutowych celów organizacji, zarówno $\mathrm{w}$ perspektywie zarządzania organizacją, jak i kontaktów $\mathrm{z}$ centralą oraz organizowania bieżącej działalności. Szczególnie w przypadku struktur terenowych działających na rozległych terytorialnie obszarach technologie 
komunikacyjne stają się fundamentem umożliwiającym działalność, ponieważ opieranie się jedynie na kontaktach działaczy face to face jest wręcz niemożliwe. Podobnie wygląda kwestia kontaktów z centralą organizacji: środki umożliwiające komunikację i przesyłanie plików drogą elektroniczną są podstawowym sposobem kontaktów, a delegacje i przesyłki dokumentów $\mathrm{w}$ formie papierowej stosuje się $\mathrm{w}$ większości tylko w wyjątkowych, wymaganych przepisami przypadkach (tu jednak uwagę zwrócić należy na podnoszone poniżej kwestie bezpieczeństwa informacyjnego).

Do najbardziej powszechnych narzędzi ICT w analizowanym przypadku należą media społecznościowe, poczta elektroniczna, komunikatory internetowe, telekonferencje na powszechnie dostępnych platformach, dyski w chmurze i telefonia. Źródeł tego stanu rzeczy należy upatrywać w niskich kosztach i powszechności ich stosowania również w prywatnym życiu większości działaczy. Poza tym działacze niezaznajomieni $\mathrm{z}$ daną technologią mogą według respondenta niniejszego case study liczyć na pomoc innych członków we wdrożeniu się w ich użytkowanie. Nie jest to jednak regułą, a tego typu inicjatywy są zazwyczaj oddolne i mogą nie sprawdzić się w przypadku jednostek, w których brak osób mających doświadczenie w użytkowaniu danego narzędzia. Problem stanowić będą również działacze nieposiadający sprzętu niezbędnego do wykorzystania danej technologii (np. zależna od rodziców młodzież, osoby starsze lub wykluczone cyfrowo). Może to wręcz zniechęcić kandydata do wstąpienia w szeregi organizacji, gdy nie ma umiejętności lub zaplecza technicznego umożliwiającego mu uczestnictwo w życiu jednostki na zasadach równych innym działaczom. Z tego względu z menedżerskiego punktu widzenia $\mathrm{w}$ interesie kierownictwa struktur terenowych leży podtrzymywanie i wspieranie wzajemnej pomocy działaczy w kwestiach technologicznych, co może mieć pozytywne przełożenie na liczbę nowych członków organizacji.

Za największą przeszkodę w stworzeniu nowych, kastomizowanych i spełniających wszystkie wymogi terenowych działaczy narzędzi ICT - takich jak zintegrowany system informatyczny umożliwiający automatyzację kreacji i przesyłania dokumentów, generowanie sprawozdań finansowych na podstawie wprowadzonych danych, e-referenda, zawierający wewnętrzny kwalifikowany podpis elektroniczny itp. albo profesjonalna organizacyjna aplikacja mobilna -uznane zostały dwie kwestie. Pierwszą z nich jest wola organów centralnych i konieczność precyzyjnego określenia obecnych i przyszłych potrzeb informacyjnych. Drugą są koszty takiego rozwiązania i konieczność znalezienia wykonawców, którzy rozumieliby specyfikę działalności organizacji angażujących się w życie publiczne, a także zapewniliby integrację nowych rozwiązań z obecnie funkcjonującymi systemami.

Często podnoszonym aspektem jest także kwestia prywatności podczas użytkowania narzędzi ICT (por.: Popiołek, Wieczorkowski 2018, s. 261-263; Wieczorkowski 2017, s. 315-318), szyfrowania komunikacji i bezpieczeństwa danych. Organizacje angażujące się w życie publiczne mają obowiązki wynikające $\mathrm{z}$ ustawy o ochronie danych osobowych (Ustawa z dnia 10 maja 2018 r. o ochronie danych osobowych), nie tylko w stosunku do swoich członków, ale także innych interesariuszy, choćby osób zgłaszających chęć zaangażowania w pracę organów obywatelskich i pretendujących do funkcji publicznych, zobowiązanych do dostarczenia na podstawie odrębnych przepisów dokumentów zawierających dane wrażliwe. Zarówno 
kierownictwo jednostki terenowej, jak i działacze zdają sobie sprawę z konieczności zachowania odpowiedniej ochrony i widzą zastosowanie dla szyfrowanych, bezpieczniejszych od ogólnodostępnych mediów społecznościowych i komunikatorów internetowych form porozumiewania się, szczególnie w przypadku kwestii wymagających zachowania tajemnicy. Wyczekiwane są także regulacje państwowe, takie jak umożliwienie udzielenia poparcia organizacjom i inicjatywom przez obywatela poprzez kwalifikowany podpis elektroniczny.

Przeprowadzone studium przypadku dowiodło, iż przed osobami pełniącymi funkcje w organizacjach angażujących się w życie publiczne stawia się wiele wyzwań nie tylko merytorycznych, tj. wymagających umiejętności typowych dla tego rodzaju podmiotów, ale i typowo menedżerskich. Nie zawsze osoby te mają w tym kierunku wykształcenie, kompetencje i praktykę, a ze względu na fakt zachowania tajemnicy organizacyjnej niekiedy nie mają możliwości uzyskania porady czy pomocy w rozwiązywaniu problemów zarządczych. Osoby pełniące funkcje prezesów, sekretarzy lub skarbników mogą więc polegać jedynie na własnych doświadczeniach zdobytych w innych obszarach lub na wiedzy i doświadczeniu innych członków organizacji. Rozwiązaniem tego problemu mogłyby być programy mentoringowe i szkolenia, które mogłyby być prowadzone z zastosowaniem nowoczesnych technologii, np. w formie webinariów, teleporad, e-szkoleń czy wideokonferencji, przy zachowaniu standardów poufności.

Ostatnią kwestią, którą warto poruszyć, jest uwzględnienie w statucie organizacji możliwości, jakie stwarzają technologie ICT. Zapisy te umożliwiają (pod określonymi w odpowiednich przepisach warunkami) zwoływanie i prowadzenie posiedzeń wieloosobowych organów organizacji w formie zakładającej wykorzystanie różnorodnych narzędzi ICT, a także dopuszczają wystąpienie z organizacji poprzez elektroniczne złożenie stosownego oświadczenia. Pozwala to na funkcjonowanie podmiotu również w sytuacjach zakazu zgromadzeń, braku odpowiednich warunków lokalowych bądź innych okoliczności, które uniemożliwiają członkom danego ciała spotkanie face to face. Dowodzi to, że organizacja stara się przystosować do warunków funkcjonowania w gospodarce elektronicznej i wychodzić naprzeciw wymogom społeczeństwa informacyjnego oraz postępującej cyfryzacji.

\section{Wnioski i podsumowanie}

W przeprowadzonych powyżej rozważaniach zidentyfikowano zarówno stan faktyczny, jak i przyszłe potrzeby w zakresie zastosowania narzędzi ICT w zarządzaniu terenowymi strukturami organizacji $\mathrm{X}$, która powołana została do angażowania się w życie publiczne. Dzięki temu osiągnięto założony cel artykułu.

Pierwsza z postawionych hipotez, tj.: narzędzia ICT są wykorzystywane w strukturach terenowych organizacji powołanych do angażowania się w życie publiczne, została zweryfikowana pozytywnie. W toku przeprowadzonych badań udowodniono, iż analizowane struktury terenowe organizacji X, która została stworzona, by angażować się w życie publiczne, wykorzystują w swojej działalności różnorodne narzędzia ICT, by wspomagać procesy zarządcze, komunikację z centralnymi organami oraz uspraw- 
niać bieżącą działalność. Działaczom organizacji obecnie trudno wyobrazić sobie komunikację oraz działanie organizacji bez dostępu do technologii ICT, które ułatwiają im porozumiewanie się, przesyłanie materiałów, planowanie działan, organizowanie, motywowanie interesariuszy oraz kontrolę i audyt wyników. Uwagę zwraca jednak kwestia bezpieczeństwa danych, która przy stosowaniu darmowych narzędzi, takich jak portale społecznościowe czy nieszyfrowane komunikatory, może doprowadzić do wycieku danych wrażliwych, kradzieży czy nawet przejęcia tożsamości.

Hipoteza druga, sformułowana w następujący sposób: narzędzia ICT usprawniają procesy zarządzania i osiąganie celów przez struktury terenowe organizacji powołanych do angażowania się w życie publiczne - także została zweryfikowana pozytywnie. Podczas badań dowiedziono, iż narzędzia ICT w sposób fundamentalny wspomagają planowanie i organizowanie działań (między innymi poprzez komunikację z innymi interesariuszami za pomocą mediów elektronicznych i telefonii), motywowanie interesariuszy (zarówno osób będących członkami organizacji, jak i z zewnątrz, np. poprzez promowanie udziału w planowanym wydarzeniu w mediach społecznościowych czy zachęty do przekazywania darowizn na działalność statutową) oraz kontrolę. W tym ostatnim przypadku zastosowanie mają wyspecjalizowane systemy, programy i narzędzia, skupiające się na danym wycinku działalności lub służące do zbierania, analizowania i prezentowania danych. W analizowanej organizacji brakuje jednak programów systematycznego wsparcia, rozwoju i szkolenia osób pełniących funkcje w organach terenowych i centralnych, przez co nie zawsze są one w stanie w pełni wykorzystać dostępną infrastrukturę do maksymalizacji efektywności zarządzania w powierzonym obszarze.

Trzecia hipoteza, zakładająca, że członkowie struktur terenowych organizacji powołanych do angażowania się w życie publiczne dostrzegają potencjał zastosowania nowych narzędzi ICT i technologii, podobnie jak poprzednie - została pozytywnie zweryfikowana. Przeprowadzone badania udowadniają, iż w każdym z wymienionych obszarów zarówno zwierzchnik terenowych struktur organizacji, jak i inni działacze dostrzegają potencjał narzędzi i technologii do tej pory nie stosowanych oraz szukają sposobów na ich aplikację. Dostrzegają jednak liczne problemy, z których za największe uważają brak środków finansowych oraz wsparcia ze strony władz centralnych.

Niniejsze studium przypadku dowodzi, że narzędzia ICT w warunkach społeczeństwa informacyjnego stały się nieodzowne także w prowadzeniu działalności zaangażowanej w życie publiczne. Narzędzia ICT umożliwiają zwiększenie efektywności procesów zarządczych, komunikacyjnych oraz usprawniają bieżącą działalność organizacji. Ich rodzaj i sposób wykorzystania może różnić się w zależności od szczebla i konkretnej organizacji, co zauważyć można po analizie dokumentacji, wzmianek medialnych i ogólnodostępnych informacji udostępnianych przez polskie organizacje angażujące się w życie publiczne. Wykorzystanie nowoczesnych technologii wiąże się jednak z wieloma zagrożeniami, które nie zawsze można zidentyfikować i podjąć odpowiednie mechanizmy zapobiegawcze w momencie wdrażania rozwiązań, co wymaga od osób pełniących funkcje kierownicze kompetencji z zakresu zarządzania ryzykiem i potencjalnymi sytuacjami kryzysowymi. Jak na razie kierownictwo i działacze organizacji nie widzą potrzeby aplikowania systemów 
i metodyk zarządzania ryzykiem. $Z$ powodu wyżej wymienionych względów dalsze badania sposobów wykorzystania narzędzi ICT w analizowanym typie organizacji może przyczynić się do rozwoju zarówno nauk o zarząadzaniu, jak i zwiększyć wiedzę menedżerską działaczy piastujących decyzyjne stanowiska w organizacjach zaangażowanych $\mathrm{w}$ życie publiczne.

\section{Literatura}

1. Adamik A., Matejun M. (2012), Organizacja i jej miejsce w otoczeniu, [w:] Zakrzewska-Bielawska A. (red.), Podstawy zarzadzania, Wolters Kluwer, Warszawa.

2. Cambria E. (2016), Affective Computing and Sentiment Analysis, „IEEE Intelligent Systems”, Vol. 31, No. 2.

3. Chomiak-Orsa I. (2016), Znaczenie technologii informacyjno-komunikacyjnych $w$ zrównoważonym rozwoju miast, „Zeszyty Naukowe Politechniki Częstochowskiej. Zarządzanie”, nr 23, t. 1.

4. Czarnota P. (2017), Wykorzystanie portalu społecznościowego Instagram w działaniach promocyjnych przedsiębiorstw, „Zeszyty Naukowe Politechniki Częstochowskiej. Zarządzanie”, nr 25, t. 1.

5. Dhakad K., Hebalkar R. (2018), Knowledge Repository Framework: Organisational Learning Accumulated in the Software Project, „International Journal of Latest Technology in Engineering, Management \& Applied Science (IJLTEMAS)", Vol. 7(5).

6. Goliński M. (2011), Społeczeństwo informacyjne - geneza koncepcji i problematyka pomiaru, Oficyna Wydawnicza SGH, Warszawa.

7. https://stat.gov.pl/metainformacje/slownik-pojec/pojecia-stosowane-w-statystyce-publicznej/1893,pojecie.html (dostęp: 21.04.2020).

8. Jaska E. (2018), Wykorzystanie nowych mediów w kreowaniu wizerunku przedsiębiorstwa „Zeszyty Naukowe Politechniki Częstochowskiej. Zarządzanie”, nr 31.

9. Jelonek D. (2011), Problem przeładowania informacyjnego w spoleczeństwie informacyjnym, „Zeszyty Naukowe Uniwersytetu Szczecińskiego. Ekonomiczne Problemy Usług”, nr 67.

10. Jelonek D. (2018), Systemy informacyjne zarzadzania przedsiębiorstwem. Perspektywa tworzenia wartości, PWE, Warszawa.

11. Karwasińska E., Rychlik M. (2009), Model i etapy tworzenia repozytorium instytucjonalnego na podstawie badań własnych i doświadczeń bibliotek zagranicznych, „Informacja dla nauki a świat zasobów cyfrowych", Biblioteka Główna Politechniki Poznańskiej, https://library. put.poznan.pl/konf_idn/art/1_2.pdf (dostęp: 28.04.2020).

12. Kiercz O. (2013), Infrastruktura ICT polskich przedsiębiorstw w układzie regionalnym, „Zeszyty Naukowe / Uniwersytet Ekonomiczny w Krakowie”, nr 907.

13. Kisielnicki J. (2015), Technologia informacyjna jako narzędzie wspomagania systemu zarzadzania, „Problemy Zarządzania”, t. 13, nr 2(52), t. 1.

14. Klimczok M., Tomczyk A. (2012), Zarządzanie wiedza - wspótczesna koncepcja zarzadzania przedsiębiorstwem, „Zeszyty Naukowe Wyższej Szkoły Humanitas. Zarządzanie”, nr 2.

15. Kłak M. (2010), Zarządzanie wiedza we współczesnym przedsiębiorstwie, Wydawnictwo Wyższej Szkoły Ekonomii i Prawa im. prof. Edwarda Lipińskiego w Kielcach, Kielce.

16. Kobyliński A. (2011), Ewolucja trendów w rankingach nowych technologii, „Zeszyty Naukowe Uniwersytetu Szczecińskiego. Ekonomiczne Problemy Usług”, nr 67.

17. Kordel P. (2010), Repozytorium wiedzy $w$ startegii zarzadzania wiedza organizacji. Studium przypadku przedsiębiorstwa branży informatycznej, „Organizacja i Zarządzanie”, nr 3.

18. Kos-Łabędowicz J. (2016), ICT jako narzędzie ułatwiające komunikację organizatorów transportu publicznego z otoczeniem, „Marketing i Zarządzanie”, $\mathrm{nr} 4(45)$.

19. Leoński W. (2014), Technologie informacyjno-komunikacyjne jako czynnik poprawy konkurencyjności polskich przedsiębiorstw, „Studia i Prace Wydziału Nauk Ekonomicznych i Zarządzania", nr 38, t. 1. 
20. Martin W.J. (2017), The Global Information Society, Routledge, Abingdon.

21. Naushad A.P.M., Jafar I. (2015), Knowledge Management in the Major Knowledge Repositories in India, „International Journal of Knowledge Engineering”, Vol. 1, No. 1, June 2015.

22. Oleksiewicz I. (2019), Bezpieczeństwo informacyjne $w$ cyberprzestrzeni a stany nadzwyczajne Rzeczypospolitej Polskiej, „Zeszyty Naukowe Politechniki Częstochowskiej. Zarządzanie”, nr 33.

23. Olszak C.M. (2016), ICT we wspomaganiu twórczości organizacyjnej-prezentacja wybranych wyników badań, ,Studia Ekonomiczne. Zeszyty Naukowe Uniwersytetu Ekonomicznego w Katowicach", nr 278.

24. Pawełoszek I. (2012), Semantyczne zarzadzanie procesami biznesowymi w organizacjach rozproszonych, „Zeszyty Naukowe Uniwersytetu Szczecińskiego. Ekonomiczne Problemy Usług", nr 87, t. 1.

25. Popiołek M., Wieczorkowski J. (2018), Prywatność a użytkowanie technologii informacyjnokomunikacyjnych - przegląd badań, „Ekonomiczne Problemy Usług”, nr 2(131), t. 1.

26. Sharma S., Bock G.-W. (2005), Factors Influencing Individual's Knowledge Seeking Behavior in Electronic KnowledgeRepository, „ECIS 2005 Proceedings”, Vol. 49, http://aisel.aisnet. org/ecis2005/49 (dostęp: 08.07.2020).

27. Skrzypek A. (2015), Zarządzanie wiedza w ujęciu teoretyków oraz w opinii przedsiębiorstw laureatów Polskiej Nagrody Jakości, „Zeszyty Naukowe Małopolskiej Wyższej Szkoły Ekonomicznej w Tarnowie", t. 26, nr 1, czerwiec 2015.

28. Sołtysik-Piorunkiewicz A., Furmankiewicz M., Ziuziański P. (2016), Metody ewaluacji narzędzi ICT w ochronie zdrowia, „Studia Informatica Pomerania”, nr 1(39).

29. Tomczyk K., Pawełoszek-Korek I. (2019), Zarządzanie relacjami z klientami banków spótdzielczych $z$ wykorzystaniem mediów społecznościowych, „Zeszyty Naukowe Politechniki Częstochowskiej. Zarządzanie", nr 33.

30. Tomski P. (2017), On Case Study Method in Entrepreneurship Research, „Zeszyty Naukowe Politechniki Częstochowskiej. Zarządzanie”, nr 27, t. 2.

31. Ustawa z dnia 10 maja 2018 r. o ochronie danych osobowych (Dz.U. 2018 poz. 1000).

32. Ustawa z dnia 27 czerwca 1997 o partiach politycznych (Dz.U. $1997 \mathrm{nr} 98$ poz. 604).

33. Warzecha K. (2018), Technologie informacyjno-komunikacyjne wykorzystywane przez mtodzież - szanse i zagrożenia, „Studia Ekonomiczne. Zeszyty Naukowe Uniwersytetu Ekonomicznego w Katowicach", nr 350.

34. Wieczorkowski J. (2017), Akceptacja naruszenia prywatności w erze Big Data, „Nierówności Społeczne a Wzrost Gospodarczy”, nr 52.

35. Wierzbica T. (2017), Komunikacyjne determinanty zmian organizacyjnych polskich partii politycznych na przełomie XX $i$ XXI wieku, dysertacja doktorska, Katowice.

36. Woźniak J., Zaskórski P. (2013), Bezpieczeństwo struktur rozproszonych $w$ sytuacjach kryzysowych, „Studia Bezpieczeństwa Narodowego”, nr 1(4).

37. Zamanani N.F., Izhar T.A.T. (2018), The Critical Success Factors of Knowledge Repository: A Proposed Framework, „International Journal of Academic Research in Business and Social Sciences", Vol. 8, No. 6.

38. Ziora L. (2016), The Sentiment Analysis as a Tool of Business Analytics in Contemporary Organizations, „Studia Ekonomiczne. Zeszyty Naukowe Uniwersytetu Ekonomicznego w Katowicach", $\mathrm{nr} 281$.

39. Zuppo C.M. (2012), Defining ICT in a Boundaryless World: The Development of a Working Hierarchy, „International Journal of Managing Information Technology (IJMIT)”, Vol. 4, No. 3 . 


\title{
THE USE OF ICT TOOLS IN FIELD STRUCTURES OF ORGANIZATION $X$
}

\begin{abstract}
Information technology and broadly understood ICT tools are becoming an inseparable element of an increasing number of areas of life and public activity. The aim of this article is to identify the needs for the use of ICT tools in the management of field structures of organization X. To achieve the aim of the article, a case study was carried out through conceptual interviews with the head of the field branch of organization $\mathrm{X}$. The collected data was analyzed, and then the most important reasons for using the selected tools affecting management in the described organization and potential directions of development of the subject were discussed.
\end{abstract}

Keywords: distributed organizations, electronic economy, field structures, ICT tools, information society, information technology 